\title{
Comparative study between polypropylene and polypropylene/poliglecaprone meshes used in the correction of abdominal wall defect in rats ${ }^{1}$
}

\author{
Estudo comparativo entre as telas de polipropileno e polipropileno/poliglecaprone utilizadas na \\ correção de defeito na parede abdominal ventral de ratos
}

\author{
Carlos Alberto Lima Utrabo', Nicolau Gregori Czeczko"I, Cesar Roberto Busato ${ }^{\text {III }}$, Mario Rodrigues Montemor-Netto ${ }^{\text {IV }}$, \\ Osvaldo Malafaiav ${ }^{v}$ Ulrich Andreas Dietz ${ }^{\mathrm{VI}}$
}

\begin{abstract}
${ }^{\mathrm{I}}$ Master in Surgery and Assistant Professor, School of Medicine, State University of Ponta Grossa (UEPG), PR, Brazil. Responsible for intellectual, scientific content of the study and critical revision.

IIPhD, Associate Professor, FEPAR and Federal University of Parana (UFPR) Curitiba-PR, Brazil. Mentor of Master degree Carlos Alberto Lima Utrabo. Responsible for conception of the scientific content with supervision of all phases of the study, manuscript writing and critical revision.

${ }^{\text {III } P h D, ~ A s s o c i a t e ~ P r o f e s s o r, ~ S c h o o l ~ o f ~ M e d i c i n e, ~ U E P G, ~ P o n t a ~ G r o s s a-P R, ~ B r a z i l . ~ H e l p e d ~ w i t h ~ t e c h n i c a l ~ p r o c e d u r e s ~ a n d ~ c o l l e c t i o n ~ o f ~ s t u d y . ~}$

${ }^{\text {IV }}$ Master in Surgery, Assistant Professor, Faculty of Medicine, UEPG, Ponta Grossa-PR, Brazil. Helped with technical procedures and collection of study.

vFull Professor, Head, Department of Surgery, FEPAR and UFPR, Coordinator of Principles of Surgery Postgraduate Program, FEPAR. Manuscript writing and critical revision.

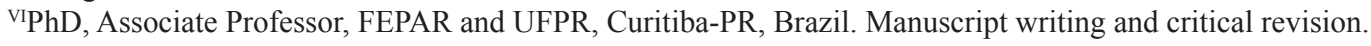

\begin{abstract}
PURPOSE: To evaluate the healing process of a defect in the ventral abdominal wall of rats, comparing the polypropylene and polypropylene/poliglecaprone meshes on the $30^{\text {th }}$ and $60^{\text {th }}$ postoperative day.

METHODS: Thirty two Wistar rats were submitted to a ventral abdominal wall defect, with integrity of the parietal peritoneum. In the repair, were used polypropylene (group A) and polypropylene/poliglecaprone (group B) meshes. The groups were subdivided into four subgroups of eight animals euthanized on the $30^{\text {th }}$ (A30 and B30) and $60^{\text {th }}$ postoperative day (A60 and B60). Fragments of the abdominal wall of the animals were submitted to macroscopic, tensiometric and histological evaluations.

RESULTS: The tensiometry on subgroup A30 showed a mean average break point of 0.78 MPa and in A60, 0.66 Mpa. In subgroup B30 it was $0.84 \mathrm{MPa}$ and in B60, 1.27 Mpa. The score of the inflammatory process showed subacute phase on A30 and B30 sub-groups and chronic inflammatory process in subgroups A30 and 60B.
\end{abstract}

CONCLUSIONS: The tensile strength was higher on the wall repaired by polypropylene/poliglecaprone mesh in the $60^{\text {th }}$ post-operative day. Histology showed higher concentration of fibrosis on the surface of the polypropylene mesh with a tendency to encapsulation. In polypropylene/poliglecaprone subgroups the histology showed higher concentration of fibrosis on the surface of mesh filaments.

Key words: Surgical Mesh. Hernia, Abdominal. Polypropylenes. Rats.

\section{RESUMO}

OBJETIVO: Avaliar a cicatrização de um defeito, na parede abdominal ventral de ratos, comparando-se as telas de polipropileno e polipropileno/poliglecaprone no $30^{\circ}$ e $60^{\circ}$ dia do pós-operatório.

MÉTODOS: Trinta e dois ratos Wistar foram submetidos à produção de defeito na parede abdominal ventral, com integridade do peritônio parietal. Na correção foram utilizadas as telas de polipropileno (grupo A) e polipropileno/poliglecaprone (grupo B). Houve subdivisão em quatro subgrupos (A30, A60, B30 e B60) de oito animais que foram submetidos à eutanásia no $30^{\circ}$ e $60^{\circ}$ dia do pósoperatório. Fragmentos da parede abdominal foram submetidos à análise macroscópica, tensiométrica e histológica.

RESULTADOS: A tensiometria no subgrupo A30 mostrou tensão média de ruptura de 0,78 Mpa e no subgrupo A60 de 0,66 MPa. No subgrupo B30 foi de 0,84 MPa e no B60 de 1,27 MPa. O escore do processo inflamatório mostrou fase subaguda nos subgrupos A30 e B30 e processo inflamatório crônico no subgrupo A60 e B60.

CONCLUSÕES: A resistência à tensão foi maior na parede reparada pela tela de polipropileno/poliglecaprone no $60^{\circ}$ dia pós-operatório. $\mathrm{Na}$ análise histológica houve maior concentração da fibrose na superfície da tela de polipropileno com tendência ao encapsulamento. Nos subgrupos polipropileno/poliglecaprone a análise histológica mostrou maior fibrose entre os filamentos da tela.

Descritores: Telas Cirúrgicas. Hérnia Abdominal. Polipropilenos. Ratos. 


\section{Introduction}

Incisional hernia is a complication that can be found among all surgeons when performing abdominal surgery. The prevalence of incisional hernia after laparotomy is $5 \%$ to $10 \%$, and when ventral hernias are repaired without the use of meshes, recurrences are above $46 \%$. It is reduced to less than $10 \%$ when meshes are used ${ }^{1}$. The polyester or polypropylene ones when used in closure of abdominal wall defects induce the formation of strong scar tissue, helping hernia correction ${ }^{2}$.

Mesh utilization for hernia correction was intensified since the 1950s, after the preliminary studies of Usher and Wallace $^{3}$. The most widely used are of polypropylene. It has been proven to increase strength of the wall, but the high porosity of the polypropylene mesh induces an intense inflammatory reaction with fibrosis, which reduces the elasticity of the wall ${ }^{4}$.

The high tensile strength and macroporous structure which results with the fibrous scar tissue around the polypropylene fibers, results on the incorporation of the mesh in the abdominal wall as a permanent repair. However, the polypropylene induces the formation of intra-abdominal adhesions.

Several studies have evaluated the use of intraperitoneal mesh $^{5-9}$. Baroncelli et al. $^{7}$ comparing the healing process between the Parietex ${ }^{\circledR}$ and Surgisis ${ }^{\circledR}$ meshes in the correction of abdominal wall defects in rabbits, observed that the Parietex ${ }^{\circledR}$ and Surgisis ${ }^{\circledR}$ were effective in correcting the defects. Araújo et al. ${ }^{8}$ assessed the intraperitoneal use of polyester with collagen and polypropylene with polyglycolic acid meshes and had the same repair results in the abdominal wall defects of rabbits. Shulz et al. ${ }^{9}$, compared absorbable polyester with collagen/elastine/polypropylene meshes to repair injuries to the abdominal wall of rabbits, and had no significant differences on its use.

The introduction of new materials with larger pores came to expose new opportunities for studies. Bellon et al. ${ }^{10}$, studying lightweight partially absorbable material, concluded that it may offer advantages over underweight non-absorbable meshes material, since less foreign body remains in the patient, enabling improvement in the abdominal wall.

Therefore, this study was scheduled in order to evaluate the healing process of a defect, produced in the ventral abdominal wall of rats, comparing the repair with polypropylene and polypropylene/poliglecaprone mesh evaluating the abdominal wall within 30 and 60 days postoperatively.

\section{Methods}

This project is part of the research line of abdominal wall healing process of the Post-Graduate Course in Principles of Surgery, Evangelical Faculty of Parana and was approved by the Ethics Committee of the institution.

Were used 32 Wistar rats (Rattus norvegicus albinus), males, young adults, with three months weighing 280 to 300 grams. The animals were divided into two groups of 16 (A and B). The groups underwent similar surgical procedures and two types of meshes were used: in group A high-density monofilament microporous polypropylene, with estimated weight of $100 \mathrm{~g} / \mathrm{m}^{2}$ (Figure 1) and in group B monofilament low density partially absorbable mesh weighting $28 \mathrm{~g} / \mathrm{m}^{2}$ with macropores between 3 to $4 \mathrm{~mm}$ in size, made by combining equal parts of polypropylene and poliglecaprone (Figure 2).

Each animal group was divided into two subgroups of eight rats. Two subgroups were polypropylene (A30 and A60), and two were polypropylene/poliglecaprone (B30 and $\mathrm{B} 60$ ) corresponding to the euthanasia occurred on the $30^{\text {th }}$ and $60^{\text {th }}$ postoperative day.
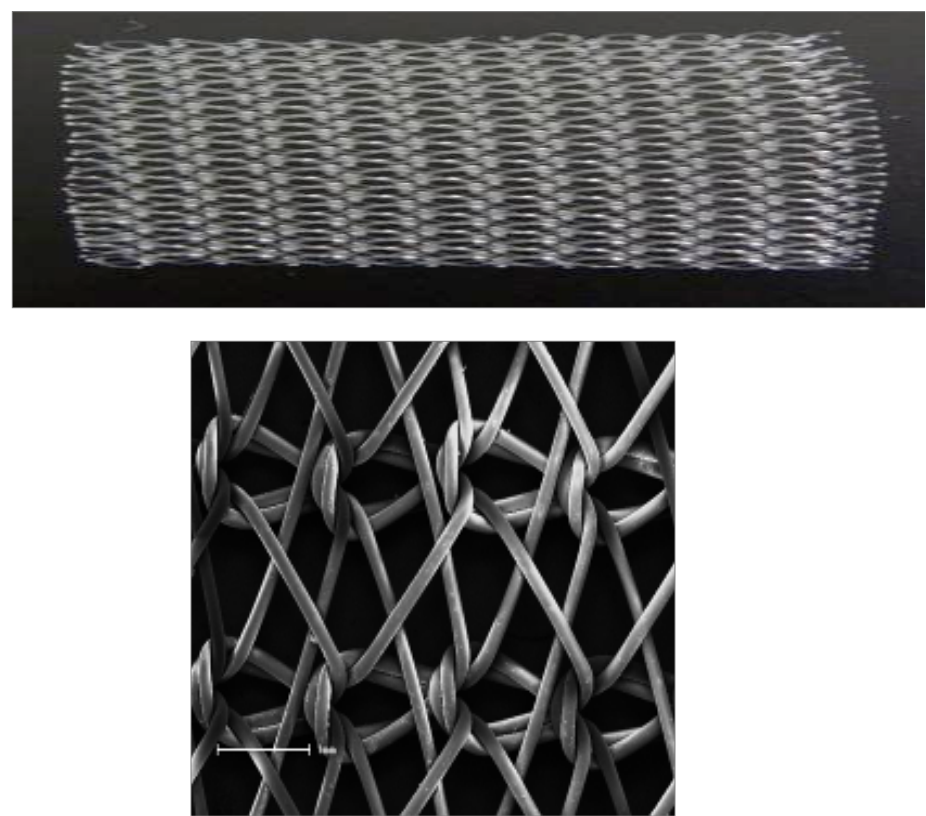

FIGURE 1 - Polypropylene mesh on normal and electron microscopy scanning aspects. 

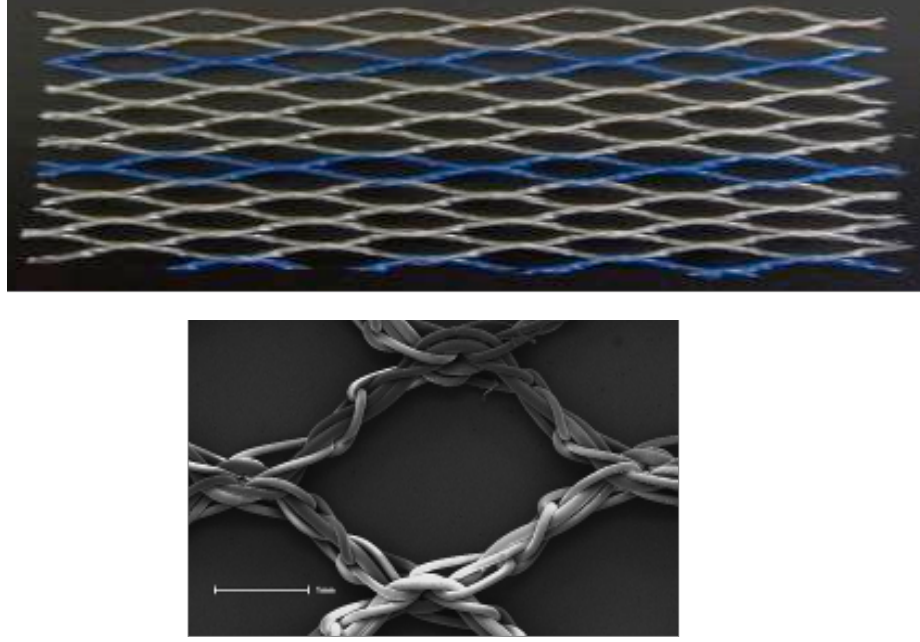

FIGURE 2 - Polypropylene/poliglecaprone on normal and electron microscopy view.

The rats underwent a preoperative fasting for 12 hours and anesthetized with application of atropine sulfate $(0.05 \mathrm{mg} / \mathrm{kg})$ intraperitoneally, and after 10 minutes, applying the mixture of $2 \%$ of xylazine hydrochloride (10 $\mathrm{mg} / \mathrm{kg}$ body weight) and ketamine hydrochloride $10 \%$ (25 mg/kg body weight) intraperitoneally. New administration was done, when needed, using half dose after 20 to 30 minutes.

It was produced $1 \times 2 \mathrm{~cm}$ defect in the abdominal wall of the animals, preserving the integrity of the parietal peritoneum. The correction of the defect was performed with mesh in an extraperitoneal area of $1.5 \times 2.5 \mathrm{~cm}$ fixing angle positions by four separate 5-0 polypropylene thread sutures, half inch from lesion edge, and four other intercalated among them to total fixation on the edges of the lesion (Figures 3 and 4).

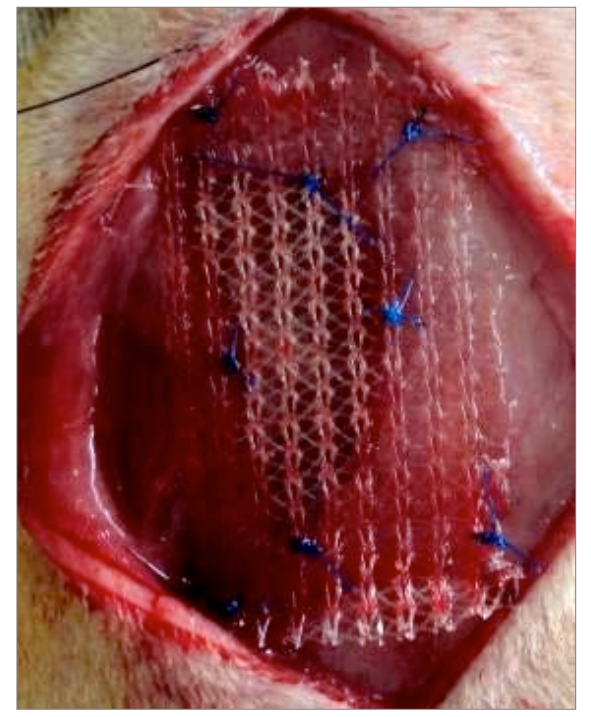

FIGURE 3 - Polypropylene mesh fixed on the lesion.

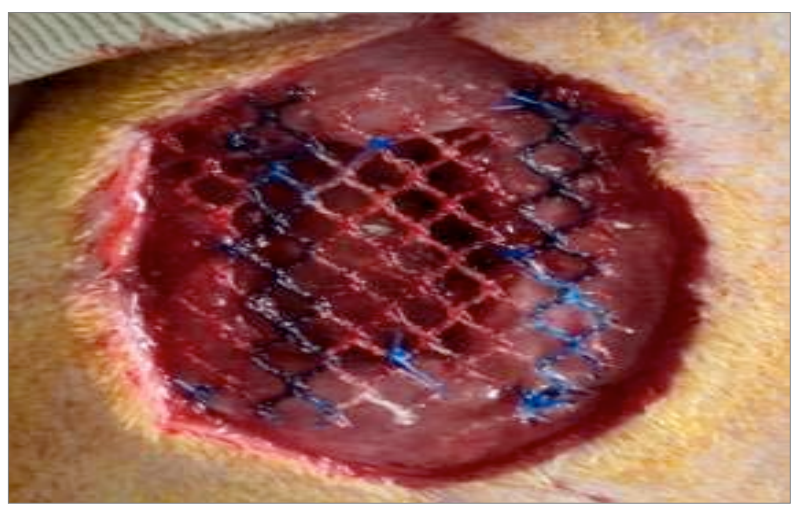

FIGURE 4 - Polypropylene/poliglecaprone mesh in final aspect after fixation.

The animals were kept under constant light and temperature conditions in standard cages, being fed with commercial diet and free access to water.

Euthanasia was performed on the $30^{\text {th }}$ postoperative day (A30 and B30) and on 60 ${ }^{\text {th }}$ day after surgery (A60 and B60). Fragment of wall was removed was divided resulting in a cranial and caudal fragment. The segments containing the mesh and musculature (cranial) without the skin, were tensiometric tested. The other segment (caudal) with skin was used for microscopic analysis and kept in 10\% formalin solution.

The cranial fragments were placed in saline solution and kept in bottles with ice. For tensiometry, was used the Shimadzu (Japan) model AG-I tensiometer with Trapezium 2 software. Were recorded the data provided by the tests (area and thickness) and the results were analyzed. The tests were performed at a temperature of $24^{\circ} \mathrm{C}$. The equipment was calibrated to a speed of $50 \mathrm{~mm} / \mathrm{min}$. The results were expressed in MPa (mega pascal). The fragment was cranially fixed in the tensiometer by the muscle tissue near the suture site.

Staining was performed by Masson trichrome and hematoxylin-eosin methods. The pathologist had no prior knowledge of the animal group. The histological analysis included foreign body granuloma, inflammatory response and fibrosis. For quantitative analysis of inflammatory parameters, neutrophils, edema, congestion, mononuclear cells, granulation tissue and fibrosis were used to quantify the phase of inflammation reaction (acute, sub-acute or chronic) ${ }^{11}$.

The results were compared by Student $t$ and MannWhitney tests with a significance level of $5 \%$. 


\section{Results}

No animal showed hematoma, infection, fistula, suture dehiscence and incisional hernia. The edges of the wounds were totally healed in all animals. It was found intra-abdominal adhesions in four animals, but with no statistically significant difference between subgroups.

In tensiometry was found that the tissue breakdown always occurred outside the suture line of the mesh in the abdominal wall of the animal. The average breakdown of the subgroup of B30 was $0.84 \mathrm{MPa}$, with no significant differences in relation to subgroup A30 ( $p=0.4702)$, whose average stress rupture was $0.78 \mathrm{Mpa}$. The results of the subgroup A60 showed an average rupture of 0.66 $\mathrm{MPa}$ and $\mathrm{B} 60$ rupture of $1.27 \mathrm{MPa}$ with a significant difference $(\mathrm{p}=0.0046)$. There was significant difference also in comparing the results of the subgroups B30 and B60 (p=0.0233) (Figure 5).

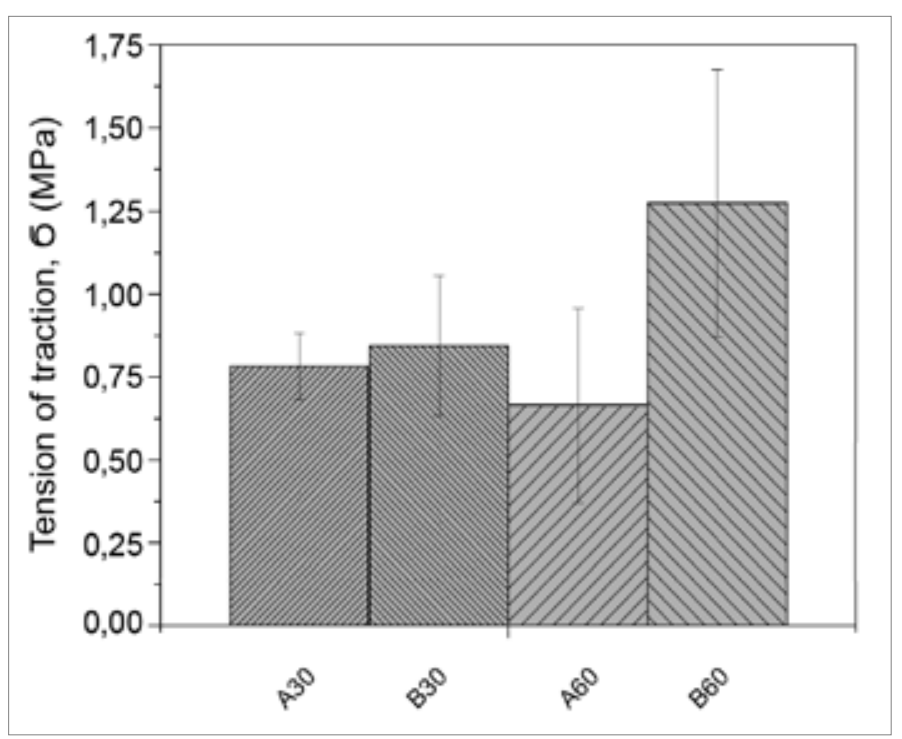

FIGURE 5 - Rupture on the four sub-groups.

Studying the microscopic evaluation of inflammatory parameters, was found a statistically significant difference when comparing the subgroups $\mathrm{A} 30$ and $\mathrm{A} 60$ ( $\mathrm{p}=0.0331)$ and the subgroups $\mathrm{B} 30$ and $\mathrm{B} 60(\mathrm{p}=0.0173)$. Comparison of inflammation scores for subgroups A30 and B30 showed that both groups were in the sub-acute phase. Fibrosis was more peripheral on subgroup A30 and distributed among the filaments on B30. The comparison of the scores for inflammation of the subgroups showed that A60 and B60, according to the score, were both in chronic inflammatory process. It was observed that fibrosis is more concentrated in the periphery of the filaments in the subgroups of B30 and B60, and the same was more pronounced in the subgroup B60. Fibrosis was more intense in subgroups A30 and A60, between the filaments of polypropylene, giving a more pronounced scar interfilamentar aspect (Figures 6, 7 and 8).

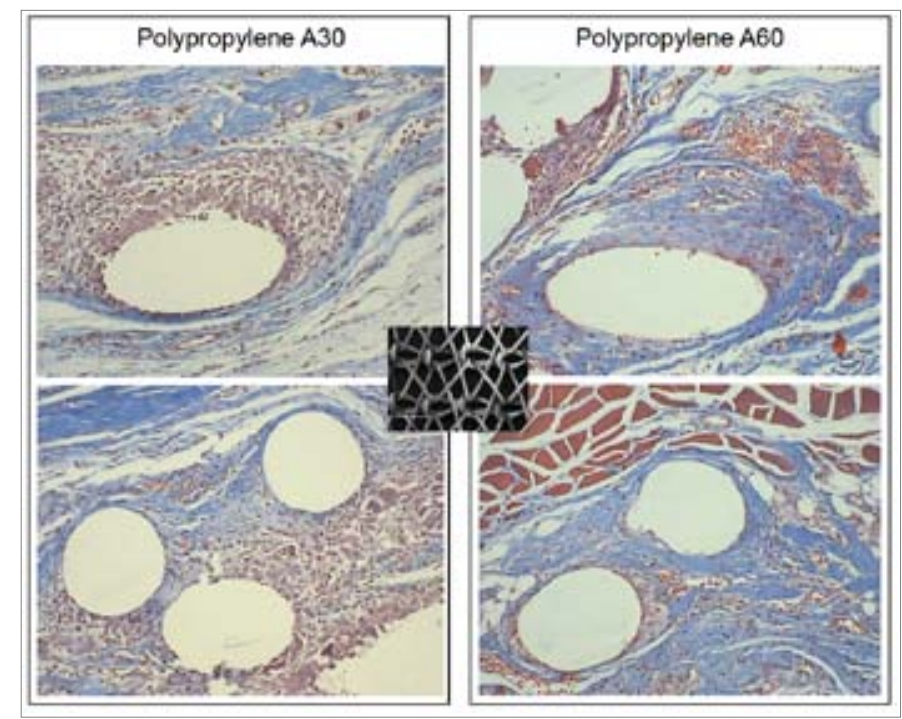

FIGURE 6 - Comparison of the phases of the inflammatory process in the subgroups A30 and A60 (Masson Tricomio 100x).

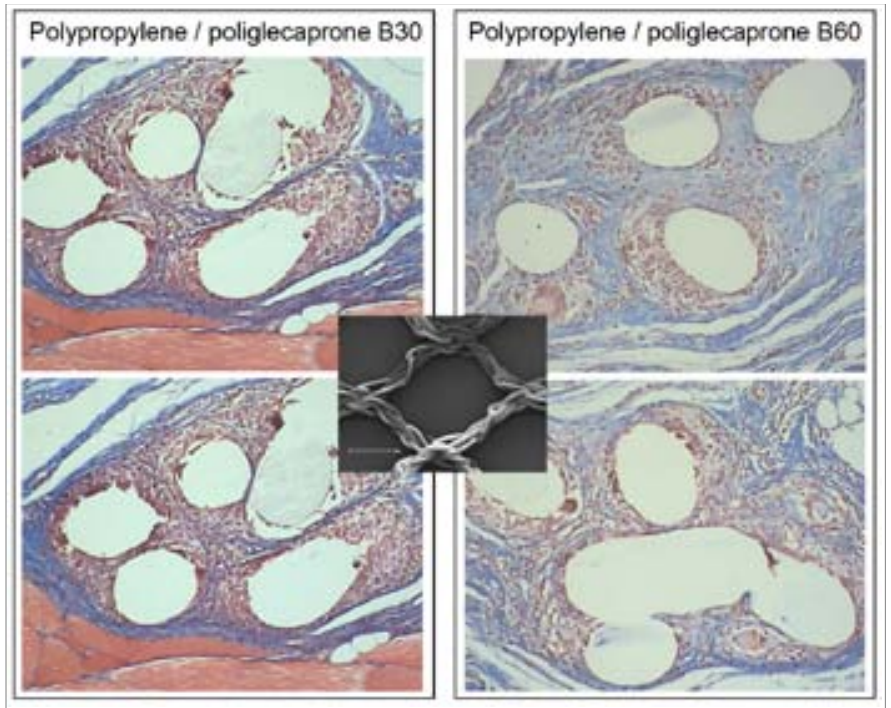

FIGURE 7 - Comparison of the inflammatory process in subgroups of B30 and B60 (Masson Tricomio 100x).

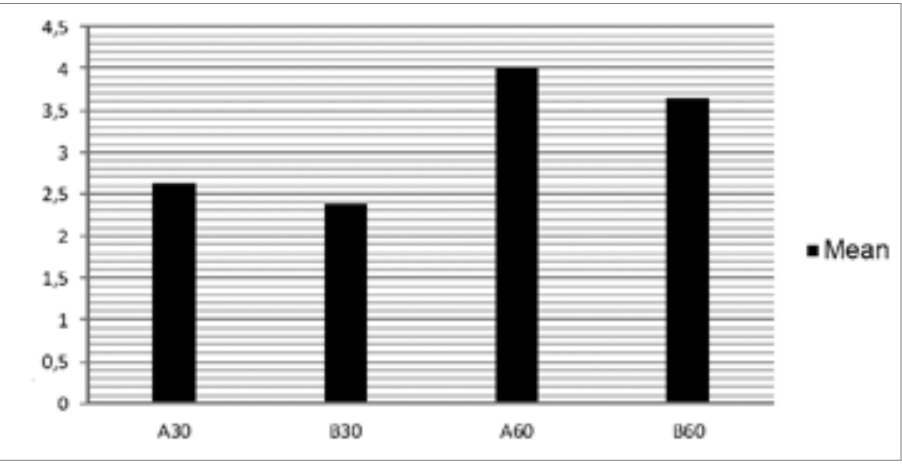

FIGURE 8 - Graphical representation of the final score of the histological classification. 


\section{Discussion}

The development of polypropylene prostheses has revolutionized surgery for abdominal wall defects. The reduction of the density of polypropylene, with the creation of lightweight prosthesis, induced a theoretically less foreign body reaction, resulting in an improvement of the abdominal wall repair and providing a better incorporation of the mesh in the abdominal wall $^{12-14}$.

The prostheses were chosen based on present extensive use of polypropylene and considering that there are few studies comparing the meshes of low and high density used in the extraperitoneal space.

The anesthesia used was the combination of intraperitoneal ketamine/xylazine, routinely used in the PostGraduate Program in Principles of Surgery of the institution. This association provides good anesthesia for up to 30 minutes, enough time for the execution of the lesion and its repair

Klinge et $a l .{ }^{13}$ in a comparative study of high and low weight meshes found seroma in $36 \%$ at high weight and $20 \%$ in the low weight. In this study, there was no seroma. Greca et al. ${ }^{12}$ paper with dogs, found $20 \%$ incidence of seroma in comparing meshes of low and high weight to correct a defect in the abdominal wall, $5 \%$ infection in the prolene high weight mesh, dehiscence in $9.1 \%$ and $4.6 \%$ respectively, and no mesh incorporation in $5 \%$ of the high weight. In this study there was no occurrence of hematoma, suture dehiscence, incisional hernia, wall infection, abscesses, fistulas or seroma in any animal.

This study found rupture always out of suture line, similar to that obtained by Aydos et al. ${ }^{15}$ and Pundek et al. ${ }^{6}$. The resistance provided by the mesh, overcomes the one of normal tissue. Comparing the results of the tensiometry, higher breakdown rupture was obtained by the subgroup B60 $(\mathrm{p}=0.0046)^{12}$. Comparing the rupture on subgroup A30 (0.78 $\mathrm{MPa})$ and $\mathrm{B} 30(0.84 \mathrm{MPa})$ was noticed no statistic significant difference $(p=0.4702)$, similar to the results of d'Acampora et al. ${ }^{4}$ comparing the tensiometry on the $28^{\text {th }}$ day after implantation of polypropylene and Vypro ${ }^{\circledR}$.

Cobb et al. ${ }^{14}$ drew attention on significant increase in deposition of collagen type I on the mesh with larger pores, low weight. The mesh with wide pores is loosely integrated with the deposition of fatty tissue intercalated with fibrosis. Instead, the mesh with pores smaller than $1 \mathrm{~mm}$, had peri-filamentar granulomas and scar tissue, forming bridges among the pores. Thus, the greater distance between the filaments prevents the formation of these bridges and smaller pores induce a greater fibrosis. Pore size has an important influence on the biocompatibility of the foreign body after implantation.

The results of this study show that despite a fixation of the prosthesis with only four points intercalated with other four is sufficient to prevent the suture dehiscence and rupture of the suture line during tensiometry in both prostheses. It is evident that after 60 days there is a greater wall strength with polypropylene/ poliglecaprone, which has pores with a diameter greater than $3 \mathrm{~mm}$, from the polypropylene prosthesis, whose pores are of diameter smaller than $1 \mathrm{~mm}$. This resistance appears more intense even when a comparison is made of tissue resistance of polypropylene/ poliglecaprone in 30 and 60 days, confirming the findings published by Greca et al. ${ }^{12}$, Pascual et al. ${ }^{16}$. This was already apparent in the Aydos et al..$^{15}$ paper. Tensiometric evaluation found that the prosthesis have a breaking strength point greater than the normal abdominal wall. Also in 1981, White et al. ${ }^{17}$ described that the complete incorporation of the mesh is an important requirement to get a solid fixation. The degree of tissue infiltration depends on the pore size of the prosthesis and proportional to the porosity. The infiltration of fibrocytes and collagen with adequate porosity occur in about a month. The healing process requires adequate pore size, in between 75 and $100 \mu \mathrm{m}$. The monofilament polypropylene mesh with pores larger than $100 \mu \mathrm{m}$ produces complete tissue infiltration incorporating the entire prosthesis.

Comparing subgroups A30 and B30 in the evaluation of inflammation in histological classification, the results showed the prevalence of subacute inflammation in both subgroups, whereas the subgroups A60 and B60 prevalence of chronic inflammatory process was found. There was no acute inflammatory process. Comparing the score of inflammation between the groups A30 and A60 there was a statistic significant difference $(p=0.0028)$, characterizing the process in subacute and chronic subgroup in the subgroup A30 A60. The same was true when comparing the scores of the inflammatory process between subgroups B30 (subacute) and $\mathrm{B} 60$ (chronic) $(\mathrm{p}=0.0047)$.

In subgroups A (polypropylene) there was a higher concentration of fibrosis in the peripheral area of the filaments, and B subgroups (polypropylene/poliglecaprone) the fibrosis was in between the filaments. This can be explained by the smaller pore of polypropylene mesh $(<1 \mathrm{~mm})$ while the polypropylene/poliglecaprone have larger ones (3-4 mm). Small pore in polypropylene filament mesh hinders the penetration of fibroblasts, providing an encapsulation of the prosthesis by fibrosis through bridging fibrosis between the filaments. Larger pores on polypropylene/poliglecaprone facilitate the penetration of fibroblasts among the filaments, providing a wall more elastic and supple. So there was a difference between the meshes in 
relation to the distribution of fibrosis.

Similar results were found by other authors ${ }^{2,14,16}$ with good integration of prostheses of high and low weight in tissue repair. High molecular weight promote encapsulation and consequent hardening of the wall; meanwhile, better distribution of fibrosis among the filaments can be found of low weight prosthesis with improvement of elasticity and pliability of the fixed wall.

\section{Conclusions}

In relation to macroscopic variables, there was no difference between the repair with both meshes. The rupture strength of the abdominal wall fragment was higher in the wall repaired by polypropylene/poliglecaprone mesh on the $60^{\text {th }}$ postoperative day, but was also demonstrated that the resistance of both meshes are suitable for the defect correction. The histological analysis showed a higher concentration of fibrosis on the surface of the polypropylene mesh with a tendency to encapsulation; among the filaments of polypropylene/poliglecaprone mesh occurred distribution of fibrous tissue with less concentration on the surface.

\section{References}

1. Butler CE, Prieto VG. Reduction of adhesions with composite AlloDerm/polypropylene mesh implants for abdominal wall reconstuction. Plast Reconstr Surg. 2004;114(2):464-73.

2. Klinge U, Klosterhalfen B, Conze J, Limberg W, Obolenski B, Ottinger AP, Schumpelick V. Modified mesh for hernia repair that is adapted to the physiology of the abdominal wall. Eur J Surg. 1998; 164:951-60.

3. Usher FC, Wallace SA. Tissue reaction to plastics; a comparison of nylon, orlon, dacron, teflon, and marlex. AMA Arch Surg. 1958;76(6):997-9.

4. D`Acampora JA, Kestering DM, Soldi MS, Rossi LF. Experimental study comparing the tensile strength of different surgical meshes following aponeurotic-muscle deformity synthesis on Wistar rats. Acta Cir Bras. 2007;22(1):22-9.

5. Araújo URMF, Czeczko NG, Deallarmi A, Hemoviski FE, Araújo HVCP. Escolha do material da tela para disposição intra-peritoneal na correção cirúrgica de defeitos herniários da parede abdominal. ABCD Arq Bras Cir Dig. 2010;23(2):118-21.

6. Pundek MRZ, Czeczko NG, Yamamoto CT, Pizzatto RF, Czeczko LEA, Dietz UA, Malafaia O. Estudo das telas cirúrgicas de polipropileno/poliglecaprone e de polipropileno/polidioxanona/ celulose oxidada regenerada na cicatrização de defeito produzido na parede abdominal de ratos. ABCD Arq Bras Cir Dig. 2010;23(2):949.

7. Baroncello JB, Czeczko NG, Malafaia O, Ribas-Filho J M, Nassif PA, Dietz AU. O uso de telas Parietex ${ }^{\circledR}$ e Surgisis $^{\circledR}$ na correção de defeitos produzidos na parede abdominal de coelhos. Arq Gastroenterol. 2008;45(4):323-9.

8. Araújo RMF, Czeczko NG, Ribas-Filho JM, Malafaia O, Budel MV, Balderrama CMSR, Zimmermann E, Dietz UA. Reparo intraperitoneal de defeitos da parede ventral do abdomen com telas de polyester com colágeno e polipropileno com ácido poliglicólico. Rev Col Bras Cir. 2009;36(3):241-9.

9. Schulz DD, Czeczko NG, Malafaia O, Schulz GJ, Czeczko LE, Garcia LS, Dietz UA. Evaluation of healing prosthetic materials polyester mesh resorbable film and collagen elastin matrix/ polypropylene used in rabbits abdominal wall defects. Acta Cir Bras. 2009;24(6):476-83.

10. Bellón JM, Rodriguez M, Garcia-Honduvilla N, Gomez-Gil V, Pascual G, Bujan J. Postimplant behavior of lightweight polypropylene meshes in an experimental model of abdominal hernia. J Invest Surg. 2008;21(5):280-7.

11. Vizzotto Junior AO, Noronha L, Scheffel DLH, Campos ACL. Influência da cisplatina administrada no pré e no pós-operatório sobre a cicatrização de anastomoses colônicas em ratos. J Bras Patol Med Lab. 2003;39(2):143-9.

12. Greca FH, de Paula JB, Biondo-Simões MLP, da Costa FD, da Silva APG, Time S, Mansur A. The influence of differing pore sizes on the biocompatibily of two polypropylene meshes in the repair of abdominal defects. Hernia. 2001;5:59-64.

13. Klinge U, Klosterhalfen B, Birkenhauer V, Junge K, Conze J, Schumpelick V. Impact of polymer size on the interface scar formation in a rat model. J Surg Res. 2002;103:208-14.

14. Cobb WS, Kercher KW, Heniford BT. The argument for lightweight polypropylene mesh in hernia repair. Surg Innov. 2005;12(1):63-9.

15. Aydos RD, Silva IS, Goldenberg S, Goldenberg A, Simões MJ, Takita LC, Nigro AJT. Estudo comparativo do efeito das telas de politetrafluoetileno expandido e de polipropileno, colocadas por laparoscopia, em hérnias ventrais produzidas em coelhos. Acta Cir Bras. 1999;14(2):59-64.

16. Pascual G, Rodriguez M, Gomez-Gil V, García-Honduvilla N, Buján J, Bellón JM. Early tissue incorporation and collagen deposition in lightweight polypropylene meshes: bioassay in an experimental model of ventral hernia. Surgery. 2008;144(3):427-35.

17. White RA, Hirose FM, Sproat RW, Lawrence RS, Nelson RG. Histophatologic observations after short-term implantation of two porous elastomers in dogs. Biomaterials. 1981;2:171-6.

\section{Correspondence:}

Carlos Alberto Lima Utrabo

Rua Augusto Ribas, 761/194

84010-300 Ponta Grossa - PR Brasil

Tel.: (55 42)3225-6071

carlosutrabo@uol.com.br

Received: November 23, 2011

Review: January 20, 2012

Accepted: February 22, 2012

Conflict of interest: none

Financial source: none

${ }^{1}$ Research performed at Postgraduate Program, Department of Surgery, Evangelic Faculty of Parana (FEPAR), Curitiba-PR, Brazil. 